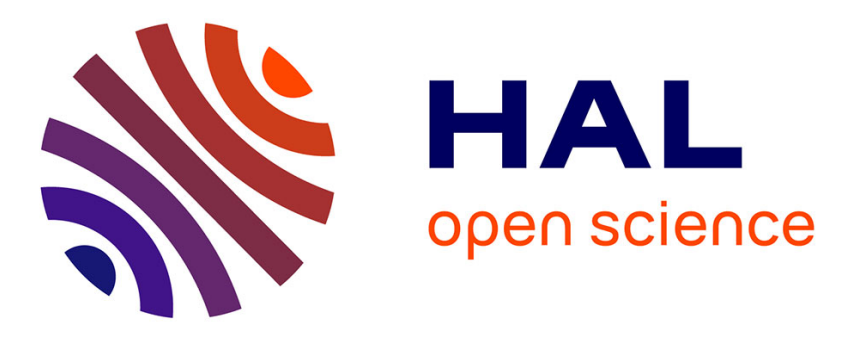

\title{
Alpha glucocorticoid receptor expression in different experimental rat models of acute lung injury
}

Giuseppina Bertorelli, Alberto Pesci, Silvia Peveri, Mario Mergoni, Attilio

Corradi, Anna Maria Cantoni, Giovanni Tincani, Antonio Bobbio, Michele Rusca, Paolo Carbognani

\section{To cite this version:}

Giuseppina Bertorelli, Alberto Pesci, Silvia Peveri, Mario Mergoni, Attilio Corradi, et al.. Alpha glucocorticoid receptor expression in different experimental rat models of acute lung injury. Pulmonary Pharmacology \& Therapeutics, 2008, 21 (1), pp.214. 10.1016/j.pupt.2007.03.001 . hal-00499146

\section{HAL Id: hal-00499146 https://hal.science/hal-00499146}

Submitted on 9 Jul 2010

HAL is a multi-disciplinary open access archive for the deposit and dissemination of scientific research documents, whether they are published or not. The documents may come from teaching and research institutions in France or abroad, or from public or private research centers.
L'archive ouverte pluridisciplinaire HAL, est destinée au dépôt et à la diffusion de documents scientifiques de niveau recherche, publiés ou non, émanant des établissements d'enseignement et de recherche français ou étrangers, des laboratoires publics ou privés. 


\section{Author's Accepted Manuscript}

Alpha glucocorticoid receptor expression in different experimental rat models of acute lung injury

Giuseppina Bertorelli, Alberto Pesci, Silvia Peveri, Mario Mergoni, Attilio Corradi, Anna Maria Cantoni, Giovanni Tincani, Antonio Bobbio, Michele Rusca, Paolo Carbognani

PII: S1094-5539(07)00038-7

DOI: $\quad$ doi:10.1016/j.pupt.2007.03.001

Reference: $\quad$ YPUPT 765

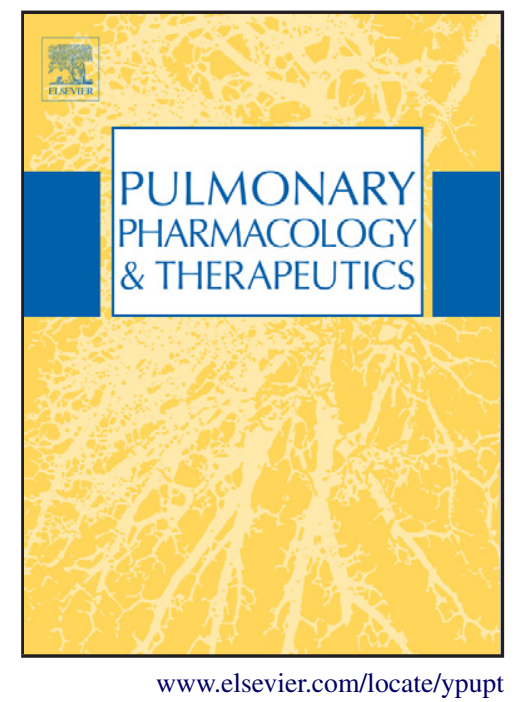

To appear in: $\quad$ Pulmonary Pharmacology \& Therapeutics

Received date: 26 July 2006

Revised date: 2 March 2007

Accepted date: 7 March 2007

Cite this article as: Giuseppina Bertorelli, Alberto Pesci, Silvia Peveri, Mario Mergoni, Attilio Corradi, Anna Maria Cantoni, Giovanni Tincani, Antonio Bobbio, Michele Rusca and Paolo Carbognani, Alpha glucocorticoid receptor expression in different experimental rat models of acute lung injury, Pulmonary Pharmacology \& Therapeutics (2007), doi:10.1016/j.pupt.2007.03.001

This is a PDF file of an unedited manuscript that has been accepted for publication. As a service to our customers we are providing this early version of the manuscript. The manuscript will undergo copyediting, typesetting, and review of the resulting galley proof before it is published in its final citable form. Please note that during the production process errors may be discovered which could affect the content, and all legal disclaimers that apply to the journal pertain. 


\section{ALPHA GLUCOCORTICOID RECEPTOR EXPRESSION IN DIFFERENT EXPERIMENTAL RAT MODELS OF ACUTE LUNG INJURY}

Giuseppina Bertorelli*, Alberto Pesci*, Silvia Peveri* ${ }^{*}$ Mario Mergoni ${ }^{\&}$, Attilio Corradi ${ }^{\#}$, Anna Maria Cantoni ${ }^{\#}$, Giovanni Tincani ${ }^{\circ}$, Antonio Bobbio ${ }^{\circ}$, Michele Rusca ${ }^{\circ}$, Paolo Carbognani ${ }^{\circ}$.

*Dipartimento di Clinica Medica, Nefrologia e Scienze della Prevenzione, ${ }^{\&}$ Terapia Intensiva, \#Dipartimento di Salute Animale, 'Dipartimento di Scienze Chirurgiche.

University of Parma. Italy.

\section{ABSTRACT}

Background and objectives: ARDS is a frequent form of hypoxiemic respiratory failure caused by the acute development of diffuse lung inflammation. Dysregulated systemic inflammation with persistent elevation of circulating inflammatory cytokines is the pathogenetic mechanism for pulmonary and extrapulmonary organ dysfunction in patients with ARDS. Glucocorticoids have a broad range of inhibitory inflammatory effects, including inhibition of cytokines transcription, cellular activation and growth factor production. They inhibit the inflammatory pathways through two specific intracellular glucocorticoid receptors (GRs), named GR $\alpha$ and GR $\beta$. The aim of our study was to evaluate the histologic evidence of inflammatory injury and the GR $\alpha$ uptake of resident and inflammatory cells in different experimental models of acute lung injury.

Methods: We studied 4 groups of rats: three different experimental rat models of lung injury and a control group. The acute lung injury was caused by barotrauma (due to an overventilation), oleic acid injection and mechanical ventilation. Results were compared to non ventilated rat control group. The duration of mechanical ventilation was of 2.5 hours. At the end of each experiment, rats were sacrificed. Lung biopsies were evaluated for morphologic changes. The immunohistochemistry was performed to study GR $\alpha$ expression.

Results: Histologic evidence of lung injury (alveolar and interstitial edema, vascular congestion, alveolar haemorrhage, emphysema, number of interstitial cells and neutrophils, and destruction of alveolar attachments) were present in all ventilated groups. Barotrauma lead to an additional inflammatory response. GR $\alpha$ expression significantly increased in the three ventilated groups compared with non ventilated groups. GR $\alpha$ expression was highest in barotrauma group. 
Conclusions: These data indicate that acute lung injury is associated with diffuse alveolar damage, up-regulation of the inflammatory response and GR $\alpha$ overexpression. Barotrauma is the most effective mechanism inducing acute lung inflammation and GR $\alpha$ overexpression.

Keywords: ARDS, lung inflammation, acute lung injury, barotrauma, glucocorticoid acquired resistance, glucocorticoid receptor $\alpha$. 


\section{INTRODUCTION}

Acute respiratory distress syndrome (ARDS) is a term applied to a relatively specific morphologic lesion of multifactorial aetiology known as diffuse alveolar damage (DAD) (1). It represents the extreme end of a spectrum of lung injury. The initiating events that lead to ARDS and its less severe manifestation, acute lung injury (ALI), are clinically widespread and diverse (2). At presentation, early ARDS manifests with severe, diffuse, and nonhomogenous acute host inflammatory response of the pulmonary lobules, leading to a breakdown in the barrier and gas exchange function of the lung (3).

Despite apparent improvement in management and outcome of ARDS, the mortality rate of ARDS remains high, ranging from $35 \%$ to $65 \%$ (4-5). Mechanical ventilation delays mortality in many patients with acute respiratory failure and is used to maintain adequate systemic oxygenation and to rest the respiratory muscles. However, over the last 2 decades, it has become evident that mechanical ventilation itself can augment or cause ALI. Recent experimental studies in various animal models have provided 3 lines of evidence suggesting that mechanical ventilation can initiate or exacerbate an inflammatory response: 1) pathologic evidence of neutrophil infiltration (6-7), 2) increased cytokine levels in lung lavage (8) and 3 ) increased cytokine levels in the systemic circulation $(9,10)$.

There are several experimental research models to construct a pathophysiological state of ARDS, attempting to fit pathogenesis (biology) with morphological (pathology) and clinical (physiology) findings (11). Intravenous injection of pure oleic acid into several different animal species has been observed to cause respiratory distress (12). Also barotrauma is characterized by the release of inflammatory mediators from cells within the lung. In animals, ventilation with the use of large tidal volumes caused the disruption of pulmonary epithelium and endothelium, lung inflammation, atelectasis, hypoxemia, and the release of inflammatory mediators $(8,13-17)$. Biotrauma is the response to barotrauma characterized by the release of inflammatory mediators from cells within the lung (18). This may help explain why most patients who die with ARDS succumb not because their lungs fail, but because of the development of multiple organ dysfunction syndrome (MODS) involving both the lungs and other organs $(19,20)$.

Dysregulated systemic inflammation with persistent elevation of circulating inflammatory cytokines over time is the pathogenetic mechanism for pulmonary and extrapulmonary organ dysfunction in patients with ARDS. Inflammation represents a double-edged sword, a 
delicate balance between the potential for tissue repair and potential for tissue injury. ALI and ARDS represent a classic example of a disease state in which that balance is shifted dramatically towards excessive tissue injury. This overwhelming inflammatory response, which targets the lung, gives rise to significant pulmonary endothelial and epithelial cell injury.

The role of glucocorticoid (GC) supplementation in patients with systemic inflammation is undergoing a cyclical reassessment stirred by new understanding of $\mathrm{GC}_{\mathrm{s}}$ ' role in modulating inflammation and immunity (21). Steroids might be considered as a subsidiary treatment during artificial mechanical ventilation.

It is now appreciated that at cellular level, transcription factors nuclear factor-kB (NF-kB) activated by inflammatory signals - and glucocorticoid receptor $\alpha(G R \alpha)$ - activated by endogenous or exogenous $\mathrm{GC}_{\mathrm{s}}$ - have diametrically opposed functions (stimulatory vs. inhibitory) in regulating inflammation (22). GR exists in at least two isoforms, GR $\alpha$ and GR $\beta$, originating from the same gene by alternative splicing of the primary transcript. GR $\alpha$ is the predominant isoform of the receptor. It has steroid binding activity and mediates either transactivation or transrepression of target genes. GR $\beta$ does not bind glucocorticoids and is unable to transactivate glucocorticoid responsive genes. The physiological function of GR $\beta$ is still unknown (23). Several mechanisms have been postulated to account for the reduced response to glucocorticoids in unresolving ARDS.

The aim of our study was to evaluate, in lungs of rats with different kinds of ALI (mechanical ventilation, oleic acid injection, barotrauma), the histologic changes and the GR $\alpha$ uptake of resident and inflammatory cells. 


\section{MATERIAL AND METHODS}

We studied 45 male Wistar rats weighing from 300 to $600 \mathrm{~g}$. The animals were treated in compliance with the Principles of Laboratory Animal Care formulated by the Institute of Laboratory Animal Resources, the Guide for the Care and Use of Laboratory Animals published by the National Institute of Health (NIH Publication No. 86-23, revised in 1985) and the Guide to the Care and Use of Experimental Animals formulated by the Canadian Council of Animal Care (CCAC $2^{\text {nd }}$ Ed 1993).

\section{Anaesthesia and preparation}

Subcutaneous injection of sodium thiopentale was used to induce $(13 \mathrm{mg} / 100 \mathrm{gr})$ and maintain (10mg/100gr every 30 minutes) anaesthesia. The animals were placed in the supine position and were intubated through a cervical tracheostomy with a 14-gauge Teflon catheter which was secured by a ligature around the trachea. Before starting mechanical ventilation pancuronium bromide $(0.1 \mathrm{mg} / \mathrm{kg})$ in iterated doses was administered intravenously for muscle relaxation. The animals were ventilated with a Harvard apparatus rodent volume ventilation (model 683, Harvard Apparatus, South Natick, MA) at a respiratory rate of 60 strokes/minute. Airway pressure was measured through a side port in the tracheal tube using a pressure transducer (Abbott Transpac II, Abbott Laboratories, Illinois) connected to a 4 channel monitor (Siemens Sirecust 1281, Siemens, Germany). The carotid artery and the jugular vein were isolated and catheterized at the neck respectively for arterial blood gases determination and direct intravenously normal saline solution $(7 \mathrm{ml} / \mathrm{Kg} / \mathrm{h})$ and oleic acid in selected animals.

Animals were divided into 4 groups:

1. Non ventilated control group: 4 animals were immediately sacrificed and both lungs were excised through a median sternotomy.

2. Ventilated group: 13 animals were ventilated with a tidal volume of $10 / \mathrm{ml} / \mathrm{Kg}$ and at a respiratory rate of 60 strokes/minute. 
3. Lung injury induced by oleic acid group: 19 rats were ventilated with a tidal volume of $10 / \mathrm{ml} / \mathrm{Kg}$ and at a respiratory rate of 60 strokes/minute. Lung injury was induced by oleic acid injection. We have used the same model described by other authors (12). Lung injury was induced using oleic acid $(0.2 \mathrm{ml} / \mathrm{kg})$ that was dissolved in an equal volume of absolute alcohol and infused by a motor syringe during a $30-\mathrm{min}$ period. To counteract circulatory instability caused by the oleic acid, $15 \mathrm{ml} / \mathrm{kg}$ of dextran (PM 70.000 daltons) in normal saline was infused over $30 \mathrm{~min}$ before the administration of oleic acid.

4. Lung injury induced by barotrauma group: in 9 animals the injury was induced by ventilation volumes that reached a plateau pressure of $40 \mathrm{~cm} \mathrm{H}_{2} \mathrm{O}$ at a respiratory rate of 60 strokes/minutes.

The overall duration of mechanical ventilation in groups 2,3 and 4 was of 2.5 hours. At the end of each experiment, all the animals were sacrificed by an intracardiac injection of potassium chloride and both of the lungs were removed through a median sternotomy.

\section{Anatomic, histologic and immunohistochemical studies}

The weight of each lung excised (expressed as weight of the lungs to weight of the rat ratio) was measured. Lung biopsies were collected from the rats of all groups and evaluated for morphologic changes. Lungs for histologic examination were inflated to $30 \mathrm{~cm} \mathrm{H}_{2} \mathrm{O}$ twice and then to $10 \mathrm{~cm} \mathrm{H}_{2} \mathrm{O}$. Lung biopsies were fixed in phosphate-buffered formalin and embedded in paraffin. Five $\mu \mathrm{m}$ thick sections were performed and stained for routine histology (H\&E, Masson's Thricomic method, Giemsa) and immunohistochemistry.

Immunohistochemistry was performed as previously described (24-26) in all biopsies with an indirect avidin-biotin complex immunoperoxidase method (Vectastasin Elite PK 6100, Vector, CA, USA) using a mouse-rabbit secondary antibody (LSAB code $n^{\circ}$ K0675, DakoCytomation, Denmark) and 3,3 diamminobenzidine (DAB code $n^{\circ} \mathrm{K} 4368$, DakoCytomation, Denmark) as chromatic substrate. The following primary antibody was used: polyclonal rabbit anti-glucocorticoid receptor $\alpha$ antibody (Bioaffinity Reagents, Golden, Colo), 1/100, also using a microwave antigen retrieval step in citrate buffer $10 \mathrm{mM}$ at pH 6.0. 
For negative control preparations, the primary antibody was replaced by either non-specific rabbit immunoglobulin or Tris-buffered saline solution.

\section{Assessment and quantification of histologic staining}

Light microscopy was performed using a Olympus microscope (Olympus $\mathrm{BH}-2$ ) at a magnification of X100. Twenty random fields were examined in each lung biopsy. Biopsies were scored for injury severity from 0 to 3 (with 0 meaning normal and 3 indicating the most severe injury) for the following histologic changes: alveolar and interstitial edema, vascular congestion, alveolar haemorrhage and emphysema. Specimens were scored for injury severity by a researcher blinded to the different groups.

Twenty random fields were examined at X1000 for the destruction of alveolar attachments. Alveolar attachments were identified as the alveolar septa that extend from the outer wall of the nonrespiratory bronchioles. Those attachments showing rupture or discontinuity were defined as destroyed alveolar attachments. The number of destroyed alveolar attachments was expressed as a percentage over the total number of alveolar attachments.

In addition, 20 random fields were examined at X1000 for the number of interstitial cells and the number of neutrophils (identified by their characteristic nucleus multilobulated and hyperchromic without nucleoli) were counted. Cells were expressed as cells/HPF.

\section{Assessment and quantification of immunohistochemical staining}

For each biopsy, all anti-glucocorticoid receptor $\alpha$ positively stained cells were counted in 20 random HPF at the magnification of X1000. Cells were expressed as GR $\alpha$ positive cells/HPF.

\section{Statistical analysis}

Non-parametric statistical tests (Mann-Whitney $U$ test) were used in the analysis. The median values and range are presented in the text and the accompanying figures and tables. Correlation coefficients were obtained by Spearman's rank-order method. In all cases a value of $p<0.05$ was considered significant. 


\section{RESULTS}

The weights of the rats' lungs are reported in Fig.1

\section{Histologic evaluation results}

Histologic evidence of lung injury was present in all ventilated groups. Within 2.5 hours after starting ventilation there were notable histologic changes, such as alveolar and interstitial edema, vascular congestion, alveolar haemorrhage, emphysema (tab 1), destruction of alveolar attachments, increased number of interstitial cells and extensive infiltrate of neutrophils (tab 2) (Fig.2b and 2c). Histologic examination of the lungs demonstrated differences in lung injury among the groups. Lung injury was patchy in all groups. There were fewer areas of normal lung in the barotrauma group. There was more lung inflation in the lungs of rats ventilated with the highest tidal volume than in other groups. In groups 2, 3 and 4 , there was a significant increase in the number of interstitial cells, neutrophils and destruction of alveolar attachments compared to group 1. The cell accumulation was highest in barotrauma group (Fig. 3a, Fig. 3b and Fig. 3c).

Immunohistochemical staining results

Immunohistochemical staining was performed successfully. GR $\alpha$ expression significantly increased in the three ventilated groups compared with non ventilated groups and was highest in the barotrauma group (Fig $4 a$ and $4 \mathrm{~b}$ ). The increased numbers of cells expressing GRa were mainly a reflection of an increase in infiltrating inflammatory cells and the number of $\mathrm{GR} \alpha+$ cells was strongly correlated with the number of neutrophils. However, also some resident cells showed an increased number of cells demonstrating GRa expression.

The number of $\mathrm{GR} \alpha+$ cells was strongly correlated with the number of neutrophils $(p<0.0001, r=0.65)$ (Figure 6a). We observed also a significant correlation between the number of neutrophils with the weight of the lung of rats $(p=0.006, r=0.43)$ (Figure $6 b)$ and the number of $G R \alpha+$ cells with the weight of the lung of rats $(p<0.009, r=0.42)$ (Figure $6 c)$. 


\section{DISCUSSION}

In our experimental models, the histologic evaluation showed the main characteristics of ARDS syndrome with diffuse inflammation and increased microvascular permeability. In particular, these findings were prominent in lung injury induced by barotrauma. We can conclude that our experimental models are effective in the ARDS inflammation assessment.

Our data showed that acute lung injury is associated with up-regulation of the inflammatory response and $\mathrm{GR} \alpha$ overexpression. Barotrauma is the most effective mechanism inducing acute lung inflammation and $\mathrm{GR} \alpha$ overexpression.

Histologic changes are in accordance with literature findings. ARDS represents a classic example of a disease state in which the potential for tissue repair and the potential for tissue injury balance is shifted dramatically towards excessive tissue injury. This inflammatory response gives rise to significant pulmonary endothelial and epithelial cell injury.

The acute lung damage following intravenous infusion of oleic acid has been studied as a model for the so-called chemical phase of post traumatic pulmonary fat embolism. Both the physiological and histological findings have been well studied. Despite the extensive work that has been done in examining oleic-acid-induced pulmonary changes, the precise mechanism of injury remain unclear (12).

The adverse consequences of mechanical ventilation were traditionally thought to be due largely to mechanical factors, such as haemodynamic compromise from decreased venous return and/or barotrauma due to overdistension of the lung. More recently research has revealed more subtle types of ventilator-induced lung injury including diffuse alveolar damage and up-regulation of the inflammatory response. The latter is referred to as biotrauma. Ranieri et al. showed that mechanical ventilation can induce a cytokine response that may be attenuated by a strategy to minimize overdistension and recruitment/derecruitment (27). Experimental animal data clearly demonstrate that overstretching of lung cells and/or allowing recruitment/derecruitment of the lung can lead to an increase in lung cytokines $(8,10,28)$. Ventilation-induced chemokine and cytokine release is associated with activation of NF-kB. Under conditions in which there is increased lung 
permeability, these cytokines may translocate from the alveolar space to the systemic circulation.

When we compared histologic changes of our two different experimental models (oleic acid and barotrauma), we found that biotrauma is the most effective model to obtain pathologic evidence of inflammation and increased microvascular permeability with an influx of large numbers of neutrophils into the lung. It is now believed that mediators derived from inflammatory cells create an injurious response directed against the microvasculature of the lung. The resultant injury leads to disruption of the alveolar-capillary interface and leakage of a protein-rich inflammatory exudate into the airspace. The inflammatory cell primarily implicated in this process is the neutrophil.

Glucocorticoids are the most important natural inhibitors of inflammation $(29,30)$. However, endogenous GCs are not always effective in suppressing ARDS inflammation. The failure to improve in ARDS (unresolving ARDS) is frequently associated with the activated GRs to downregulate the transcription of inflammatory cytokines despite elevated levels of circulating cortisol, a condition defined as systemic inflammation-associated acquired GC resistance and potentially reversible with prolonged GC supplementation. Meduri GU et al. have shown that, in patients with unresolving ARDS, normal peripheral blood leukocytes exposed to plasma samples collected during prolonged methylprednisolone treatment exhibited a progressive increase in cytoplasmic binding of GR $\alpha$ to NF-kB and a concomitant reduction in NF-kB binding to DNA and transcription of TNF $\alpha$ and the IL-1 $\beta$ (31).

Failure to suppress inflammation could be due to tissue resistance to GCs or inadequacy of the level and duration of endogenous GC elevation to suppress host inflammatory response (32). GC-mediated resistance was originally described as a primary inherited familial syndrome, $(33,34)$ and was recently recognized as an acquired condition. Several in vitro studies have shown that cytokines may induce resistance to GCs by reducing GR binding affinity to cortisol (35-37). Such abnormalities of GR function were demonstrated in T cells incubated with a combination of IL-2 and IL-4 (36), IL-1 $\beta$, IL-6, interferon (INF)- $\gamma(35)$ and IL13 (36). GC resistance was induced in a cytokine concentration-dependent fashion and was reversed by the removal of cytokines (36). 
GR-mediated resistance in the presence of systemic inflammation was also studied in experimental models of sepsis and sepsis-induced ARDS. In a sheep model of sepsisinduced ARDS (38-40), maximal binding capacity of GR decreased continuously after endotoxin infusion, while there was a marked elevation of cortisol levels (41). The reduced GR binding correlates negatively with phospholipase $A_{2}$ activity, a gene that is stimulated by NF-kB. In a rat model of septic shock, GR blockade by minfepristone exacerbated the physiologic and pathologic changes induced by endotoxemia (42). Phospholipase $A_{2}$ activity in rats with $80 \%$ GR blockade was more marked than in those with $50 \%$ GR blockade (42). Monocytes taken from patients with sepsis developed near total GC resistance in vitro when cytokines, especially IL-2, were added (38). Several inflammatory cytokines, including TNF $\alpha$, IL-1 $\beta$, and IL-6 activate NF-kB (41). It has been suggested that when cytokine-activated NFkB forms protein-protein complexes with activated GR, the availability and activity of effective GR molecules are reduced $(42,43)$. This functional reduction in GR availability is associated with an increased number of GR $(42,43)$.

The increase in GR $\beta$ isoform expression is considered responsible for glucocorticoid resistance. However, in this case we did not observe any increase in the production of GR $\beta$. related to resistance to GCs observed in different models of ALI. The lack of change in GRß expression is interesting as neutrophils have previously been reported to express high levels of GRß in man $(44,45)$. This could reflect the possibility that in rat GRß has a distinct function compared to that in human. In this regard, we know that some animal models of systemic glucocorticoid resistance such as New World monkeys have approximately 10-fold higher GRß than GRa level (46) and, on the contrary, mice, known to be extremely steroidsensitive animals, do not appear to have GRß (47).

We observed an increased number of GRa positive cells related to the increased number of neutrophils. However, neutrophils have previously been expressed in high levels of GRß in man $(44,45)$. This could reflect the possibility that in rat GRß has a distinct function compared to that in humans. In this regard, we know that some animal models of systemic glucocorticoid resistance such as New World monkeys have approximately 10-fold higher GRß than GRa levels (46) and, on the contrary, mice, known to be extremely steroidsensitive animals, do not appear to have GRß (47). 
The concept of acquired resistance can explain the significantly increased number of GR $\alpha$ positive cells that we found in the three ventilated groups compared with the non ventilated groups. In the barotrauma group, where the inflammatory changes were prominent, the number of $\mathrm{GR} \alpha$ was highest. 


\section{References}

1. Katzenstein AL, Bloor CM, Leibow AA. Diffuse alveolar damage - the role of oxygen, shock, and related factors. A review. Am J Pathol 1976; 85:209-228.

2. Wallace WAH, Donnelly SC. Pathogenesis of acute microvascular lung injury and the acute respiratory distress syndrome. Eur Respir Mon 2002; 20:22-32.

3. Steinberg KP, Hudson LD. Acute lung injury and acute respiratory distress syndrome. The clinical syndrome. Clin Chest Med 2000; 21:401-417.

4. Milberg JA, Davis DR, Steinberg KP, Hudson LD. Improved survival of patients with acute respiratory distress syndrome (ARDS): 1983-1993. JAMA. 1995; 273:306-309.

5. Suchyta MR, Clemmer TP, Orme JF Jr, et al. Increased survival of ARDS patients with severe hypoxemia (ECMO criteria). Chest 1991; 99:951-955.

6. Hamilton PP, Onayemi A, Smyth JA, et al. Comparison of conventional and highfrequency ventilation: oxygenation and lung pathology. J Appl Physiol. 1983; 55:131-138.

7. Kawano T, Mori S, Cybulsky M, et al. Effect of granulocyte depletion in a ventilated surfactant-deplete lung. J Appl Physiol. 1987; 62:27-33.

8. Tremblay L, Valenza F, Ribeiro SP, Li J, Slutsky AS. Injurious ventilatory strategies increase cytokines and c-fos m-RNA expression in an isolated rat lung model. J Clin Invest 1997;99:944-952.

9. Chiumello D, Pristine G, Baba A, Slutsky AS. Mechanical ventilation affects local and systemic cytokines in an animal model of ARDS. A J Respir Crit Care Med. 1998;157:A45.

10. von Bethmann AN, Brasch F, Nusing R, Vogt K, Volk HD, Muller KM, Wendel A, Uhlig S. Hyperventilation induces release of cytokines from perfused mouse lung. Am J Respir Crit Care Med. 1998;157:263-272. 
11. Cotran RS, Kumar V, Robbins SL. Cellular injury and cellular death. In Pathologic basis of diseases. Cotran RS, Kumar V, Robbins SL, Eds. WB Saunders. Philadelphia.1994: 1-34.

12. Dickey BF, Thrall RS, McCormick JR, Ward PA. Oleic-acid-induced lung injury in the rat. Failure of indomethacin treatment or complement depletion to ablate lung injury. Am J Pathol. 1981;103:376-383.

13. Tsuno K, Miura K, Takeya M, Kolobow T, Morioka T. Histopathologic pulmonary changes from mechanical ventilation at high peak airway pressures. Am Rev Respir Dis 1991;143:1115-1120.

14. Parker JC, Hernandez LA, Peevy KJ. Mechanisms of ventilator-induced lung injury. Crit Care Med 1993;21:131-143.

15. Dreyfuss D, Basset G, Soler P, Saumon G. Intermittent positive-pressure hyperventilation with high inflation pressures produces pulmonary microvascular injury in rats. Am Rev Respir Dis 1985;132:880-884.

16. Webb HH, Tierney DF. Experimental pulmonary edema due to intermittent positive pressure ventilation with high inflation pressures: protection by positive end-expiratory pressure. Am Rev Respir Dis 1974;110:556-565.

17. Kolobow $T$, Moretti MP, Fumagalli $R$, et al. Severe impairment in lung function induced by high peak airway pressure during mechanical ventilation: an experimental study. Am Rev Respir Dis 1987;135:312-315.

18. Tremblay LN, Slutsky AS. Ventilator-induced injury: from barotrauma to biotrauma. Proc Assoc Am Physicians 1998; 110:482-488.

19. Slutsky AS, Tremblay LN. Multiple system organ failure. Is mechanical ventilation a contributing factor? Am J Resp Crit Care Med 1998; 157:1721-1725.

20. The Acute Respiratory Distress Syndrome Network. Ventilation with lower tidal volumes as compared with traditional tidal volumes for acute lung injury and the acute respiratory distress syndrome. N Engl J Med 2000; 342-1301-1308. 
21. Franchimont D, Kino T, Galon J, Meduri GU, Chrousos G. Glucocorticoids and inflammation revisited: the state of the art. NIH Clinical Staff Conference. Neuroimmunomodulation. 2003;10:247-260.

22. Baeuerle PA, Baltimore D. Activation of DNA-binding activity in an apparently cytoplasmic precursor of the NF-kappa B transcription factor. Cell. 1988; 53:211-217.

23. Oakley RH, Sar M, Cidlowski JA. The human glucocorticoid receptor beta isoform. Expression, biochemical properties, and putative function. J Biol Chem. 1996;271:95509559 .

24. Bocchino V, Bertorelli G, Bertrand CP, Ponath PD, Newman W, Franco C, Marruchella A, Merlini S, Del Donno M, Zhuo X, Olivieri D. Eotaxin and CCR3 are up-regulated in exacerbations of chronic bronchitis. Allergy. 2002; 57:17-22.

25. Bertorelli G, Bocchino V, Zhou X, Zanini A, Bernini MV, Damia R, Di Comite V, Grima P, Olivieri D. Dendritic cell number is related to IL-4 expression in the airways of atopic asthmatic subjects. Allergy. 2000; 55:449-454.

26. Bocchino V, Bertorelli G, Zhuo X, Grima P, Di Comite V, Damia R, Chetta A, Del Donno M, Foresi A, Casalini A, Testi R, Olivieri D. Short-term treatment with a low dose of inhaled fluticasone propionate decreases the number of CD1a+ dendritic cells in asthmatic airways. Pulm Pharmacol Ther. 1997;10:253-259.

27. Ranieri VM, Suter PM, Tortorella C, De Tullio R, Dayer JM, Brienza A, Bruno F, Slutsky AS. Effect of mechanical ventilation on inflammatory mediators in patients with acute respiratory distress syndrome. A randomized controlled trial. JAMA 1999; 282:54-61.

28. Held HD, Boettcher S, Hamann L, Uhlig S. Ventilation-induced chemokine and cytokine release is associated with activation of NF-kB Am J Respir Crit Care Med 2001; 163:711716.

29. Chrousos GP. The hypothalamic-pituitary-adrenal axis and immune-mediated inflammation. N Engl J Med. 1995; 332:1351-1362. 
30. Bertorelli G, Bocchino V, Olivieri D. Heat shock protein interactions with the glucocorticoid receptor. Pulm Pharmacol Ther. 1998;11:7-12.

31. Meduri GU, Tolley EA, Chrousos GP, Stentz F. Prolonged methylprednisolone treatment suppresses systemic inflammation in patients with unresolving acute respiratory distress syndrome: evidence for inadequate endogenous glucocorticoid secretion and inflammationinduced immune cell resistance to glucocorticoids. Am J Respir Crit Care Med. 2002;165:983-991.

32. Annane D, Sebille V, Troche G, Raphael JC, Gajdos P, Bellissant E. A 3-level prognostic classification in septic shock based on cortisol levels and cortisol response to corticotropin. JAMA. 2000; 283:1038-1045.

33. Chrousos GP, Detera-Wadleigh SD, Karl M. Syndromes of glucocorticoid resistance. Ann Intern Med 1993; 119: 1113-1124.

34. Lamberts SW, Koper JW, Biemond P, den Holder FH, de Jong FH. Cortisol receptor resistance: the variability of its clinical presentation and response to treatment. J Clin Endocrinol Metab. 1992;74:313-321.

35. Almawi WY, Lipman ML, Stevens AC, Zanker B, Hadro ET, Strom TB. Abrogation of glucocorticoid-mediated inhibition of T cell proliferation by the synergistic action of IL-1, IL-6, and IFN-gamma. J Immunol. 1991;146:3523-3527.

36. Kam JC, Szefler SJ, Surs W, Sher ER, Leung DY. Combination IL-2 and IL-4 reduces glucocorticoid receptor-binding affinity and T cell response to glucocorticoids. J Immunol. 1993;151:3460-3466.

37. Spahn JD, Szefler SJ, Surs W, Doherty DE, Nimmagadda SR, Leung DY. A novel action of IL-13: induction of diminished monocyte glucocorticoid receptor-binding affinity. J Immunol. 1996 Sep 15;157(6):2654-2659. 
38. Molijn GJ, et al. Differential adaptation of glucocorticoid sensitivity of peripherial blood mononuclear leukocytes in patients with sepsis or septic shock. J Clin Endocrinol Metab 1995; 80:1799-1803.

39. Liu LY, et al. Changes of pulmonary glucocorticoid receptor and phospholipase A2 in sheep with acute lung injury after high dose endotoxin infusion. Am Rev Respir Dis 1993; 148:878-881.

40. Fan J, et al. Effect of glucocorticoid receptor (GR) blockade on endotoxemia in rats. Circ Shockl 1994; 42:76-82.

41. Baeuerle PA, Baichwal VR. NF-kappa B as a frequent target for immuno-suppressive and anti-inflammatory molecules. Adv. Immunol. 1997; 65:111-137.

42. Bamberger CM, Schulte HM, Chrousos GP. Molecular determinants of glucocorticoid receptor function and tissue sensitivity to glucocorticoids. Endocr Rev 1996; 17:245-261.

43. Barnes PJ, Greening AP, Crompton GK. Glucocorticoid resistance in asthma. Am J Respir Crit Care Med 1995; 152:S125-140.

44. Strickland I, Kisich K, Hauk PJ, Vottero A, Chrousos GP, Klemm DJ, Leung DYM. High constitutive glucocorticoid receptor $\beta$ in human neutrophils enables them to reduce their spontaneous rate of cell death in response to corticoids. J Exp Med. 2001; 193:585-593.

45. Xu Q, Leung DYM, Kisich K. Serine-arginine-rich protein p30 directs alternative splicing of glucocorticoid receptor pre-mRNA to glucocorticoid receptor $\beta$ in neutrophils. J Biol Chem. 2003; 278:27112-27118.

46. Vottero A, Chrousos GP. Glucocrticoid receptor beta: view I. Trends Endocrinol Metab.1999; 10:333-338.

47. Otto C, Reichardt HM, Schutz G. Absence of glucocorticoid receptor $\beta$ in mice. JBC 1997; 272:26665-26668. 
Tables

Table 1 - Histologic evaluation results

\begin{tabular}{|l|c|c|c|c|}
\hline $\begin{array}{l}\text { Parameters } \\
\text { (HPF) }\end{array}$ & $\begin{array}{c}\text { Non Ventilated } \\
\text { Controls }\end{array}$ & $\begin{array}{c}\text { Ventilated } \\
\text { Group }\end{array}$ & $\begin{array}{c}\text { Oleic Acid } \\
\text { Group }\end{array}$ & $\begin{array}{c}\text { Barotrauma } \\
\text { Group }\end{array}$ \\
\hline $\begin{array}{l}\text { Vascular } \\
\text { Congestion }\end{array}$ & $1(0-1)$ & $1(0-2)$ & $1(0-3)$ & $1(1-2)$ \\
\hline $\begin{array}{l}\text { Intraalveolar } \\
\text { Edema }\end{array}$ & $0(0-0)$ & $0(0-1)$ & $1(0-3)$ & $1(0-2)$ \\
\hline $\begin{array}{l}\text { Intraalveolar } \\
\text { Haemorrhage }\end{array}$ & $0(0-0)$ & $0(0-0)$ & $0(0-2)$ & $1(0-1)$ \\
\hline Emphysema & $0(0-0)$ & $1(0-3)$ & $0(0-2)$ & $2(2-3)$ \\
\hline $\begin{array}{l}\text { Interstitial } \\
\text { Edema }\end{array}$ & $1(0-1)$ & $1(0-3)$ & $1(0-3)$ & $1(1-1)$ \\
\hline
\end{tabular}

Values were expressed as median (range) 
Table 2 - Histologic evaluation results

\begin{tabular}{|l|c|c|c|c|}
\hline $\begin{array}{l}\text { Parameters } \\
\text { (HPF) }\end{array}$ & $\begin{array}{c}\text { Non Ventilated } \\
\text { Controls }\end{array}$ & $\begin{array}{c}\text { Ventilated } \\
\text { Group }\end{array}$ & $\begin{array}{c}\text { Oleic Acid } \\
\text { Group }\end{array}$ & $\begin{array}{c}\text { Barotrauma } \\
\text { Group }\end{array}$ \\
\hline $\begin{array}{l}\text { Interstitial } \\
\text { cells }\end{array}$ & $\begin{array}{c}17.90 \\
(17.50-21.00)\end{array}$ & $\begin{array}{c}39.80 \\
(24.00-49.60)\end{array}$ & $\begin{array}{c}32.50 \\
(22.40-44.60)\end{array}$ & $\begin{array}{c}27.40 \\
(22.50-65.50)\end{array}$ \\
\hline $\begin{array}{l}\text { Neutrophils } \\
0.85\end{array}$ & $\begin{array}{c}1.20 \\
(1.00-1.90)\end{array}$ & $\begin{array}{c}1.80 \\
(0.50-3.80)\end{array}$ & $\begin{array}{c}3.60 \\
(2.80-7.50)\end{array}$ \\
\hline $\begin{array}{l}\text { Destruction of } \\
\text { alveolar } \\
\text { attachments }\end{array}$ & $(10.80-14.20)$ & $(13.40-26.30)$ & $(13.10-26.40)$ & $(14.80-24.90)$ \\
\hline
\end{tabular}

Values were expressed as median (range) 


\section{Figure captions}

Fig. 1 The weights of the rats' lungs in ventilated, oleic acid and barotrauma groups.

Fig. 2

a) Hematoxylin-eosin staining. Microphotograph from control animals.

b) Hematoxylin-eosin staining. Microphotograph showing an intense rupture of septal walls in a rat ventilated with high inflation flow (arrows). Original magnification x100.

c) Hematoxylin-eosin staining. Microphotograph showing an intense cellular infiltration within the alveolar walls from a rat ventilated with high inflation flow. There is interstitial and intraalveolar edema (solid line arrows) and some haemorrhage (intermitted line arrows). Rupture of septal walls is also present (arrow points). Original magnification $\times 200$.

\section{Fig. 3}

Number of interstitial cells (a), neutrophils (b) and destruction of alveolar attachments (c) in the lungs of ventilated, oleic acid and barotrauma groups compared to control group.

\section{Fig.4}

Immunohistochemistry staining of lung tissue for expression of GR $\alpha$. Representative images of $\mathrm{GR} \alpha$ immunostaining in lung preparations from non-ventilated rat lung (a) compared with rat lung from barotrauma group (b). Note the increased number of $G R \alpha$ immunoreactive cells in alveolar walls of the lung from barotrauma rat group (b) (brown spots) compared with the lung from non-ventilated rat group (a) (brown spots indicated by arrows).

\section{Fig. 5}

GR $\alpha$ (a) expression in the lungs of three ventilated experimental groups compared with non ventilated group.

\section{Fig. 6}

Correlation between the number of $\mathrm{GR} \alpha+$ cells and the number of neutrophils (a), the number of neutrophils with the weight of the lung of rats (b) and the number of GR $\alpha+$ cells with the weight of the lung of rats (c). 
Figure 1

\section{Corrected lung weight}

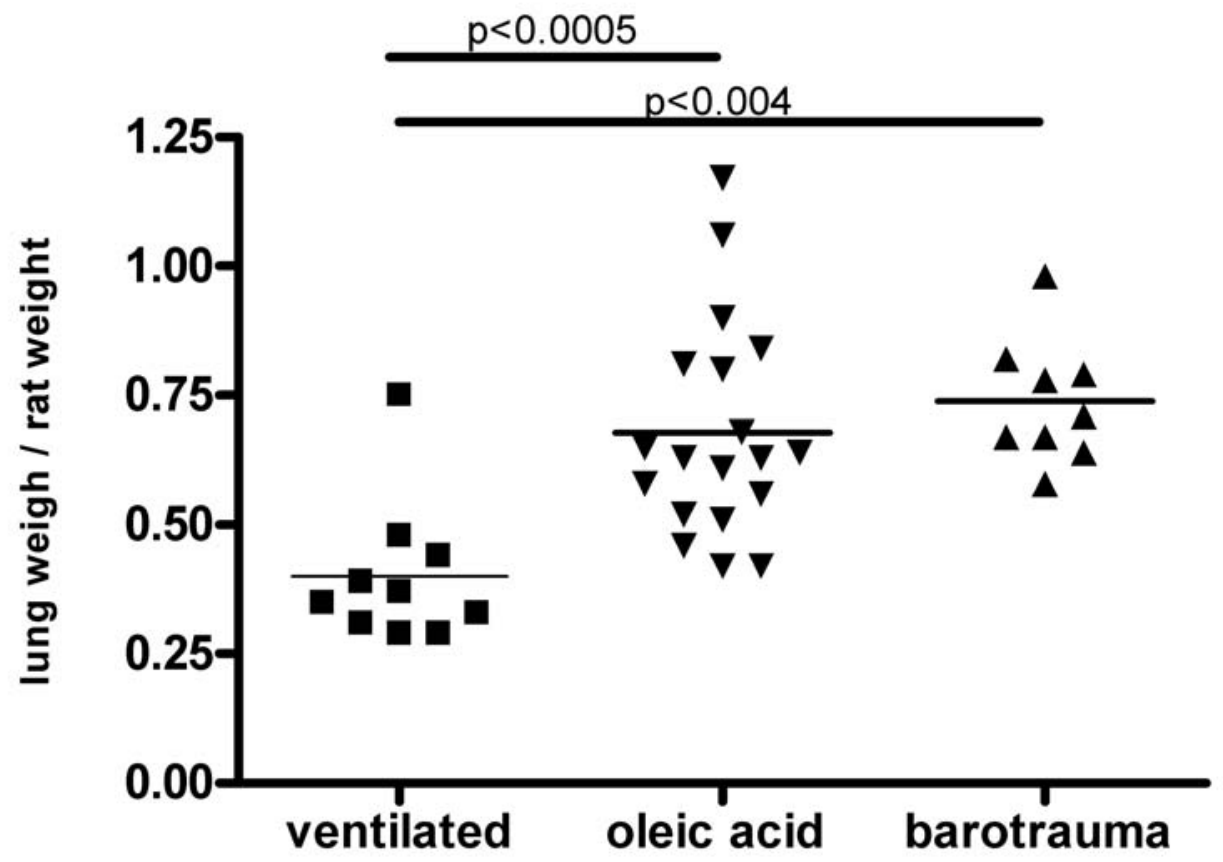

fig 1 


\section{Figure 2}

Fig. $2 \mathrm{a}$

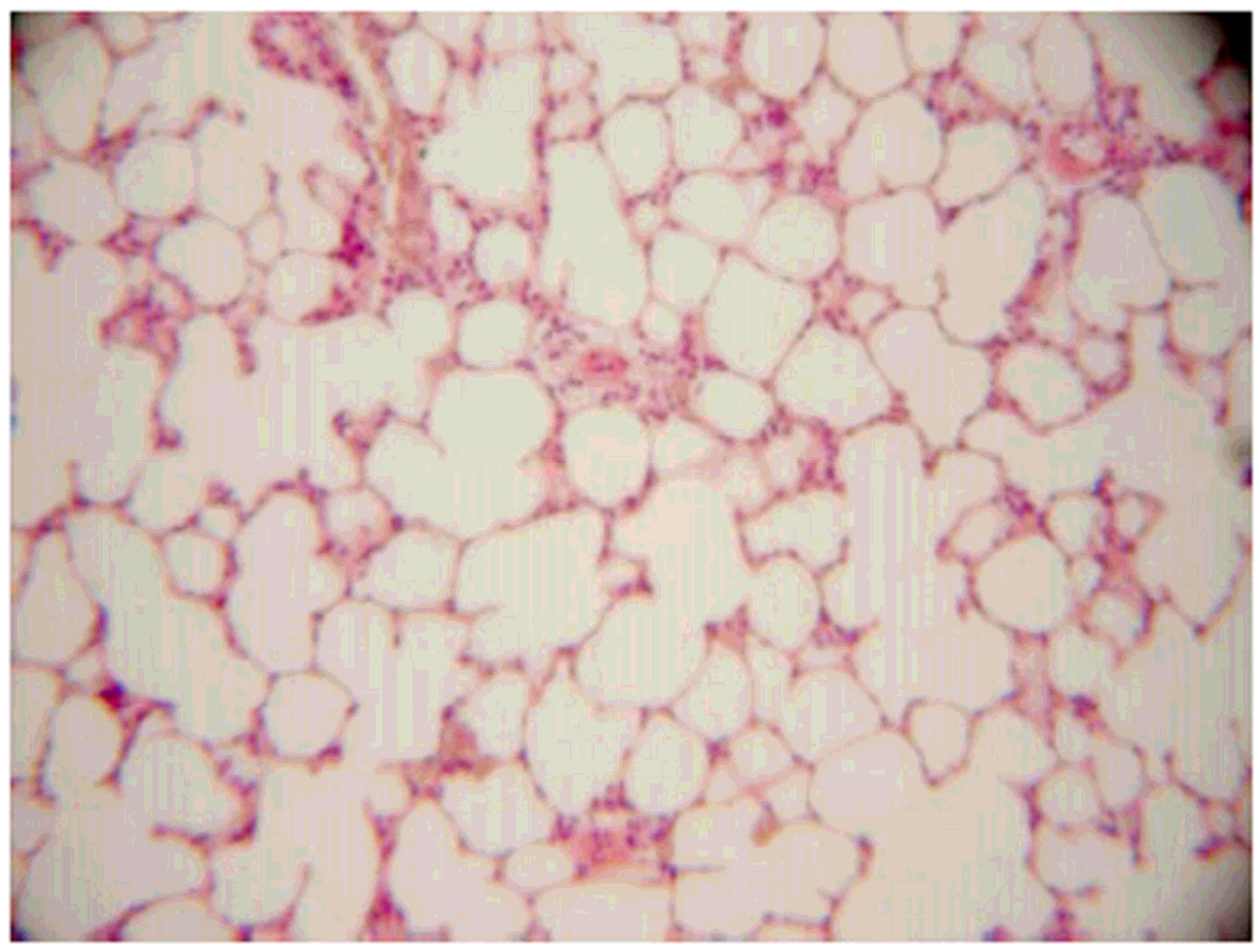

Fig. 2b

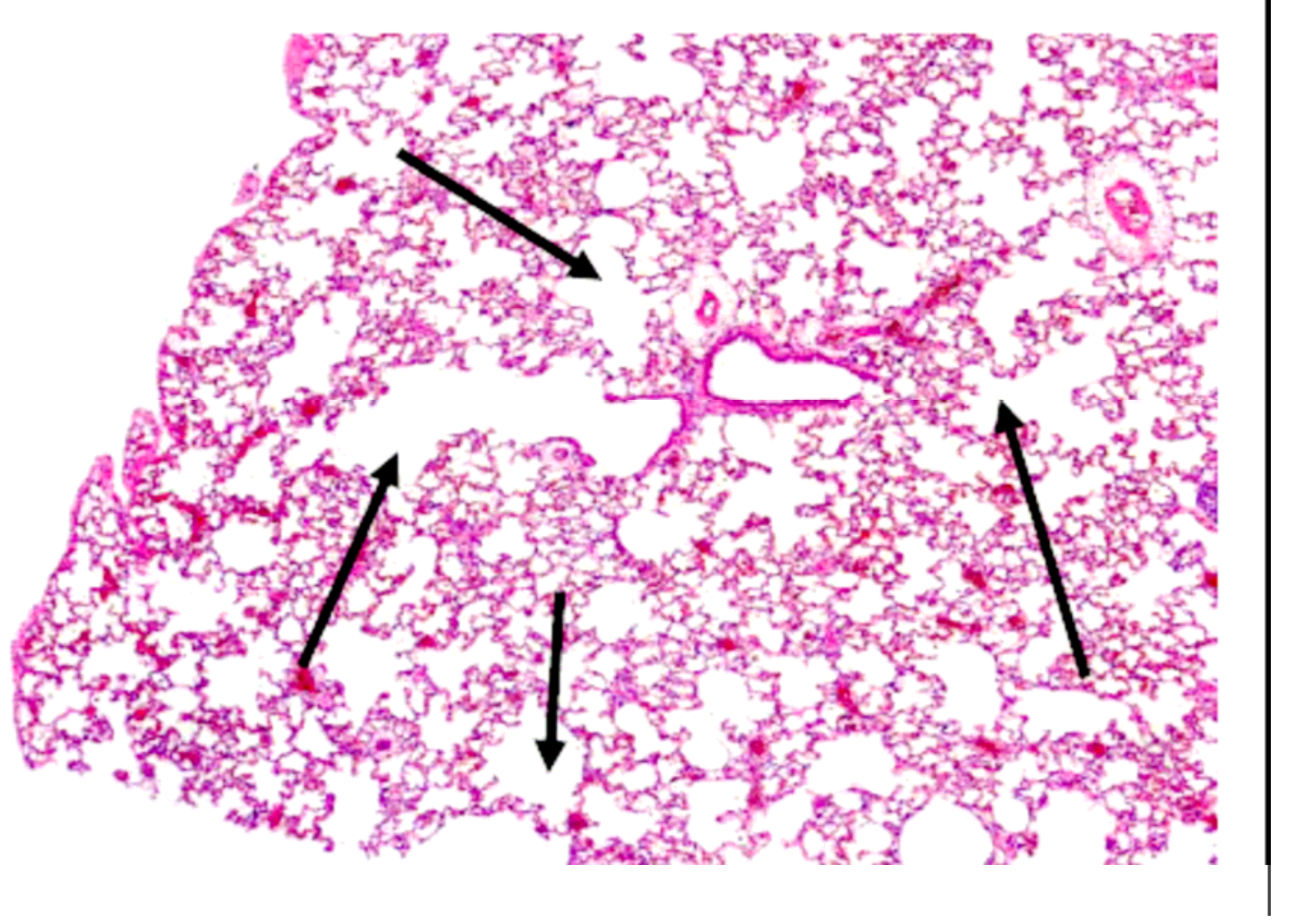




\section{Fig. $2 \mathrm{c}$}

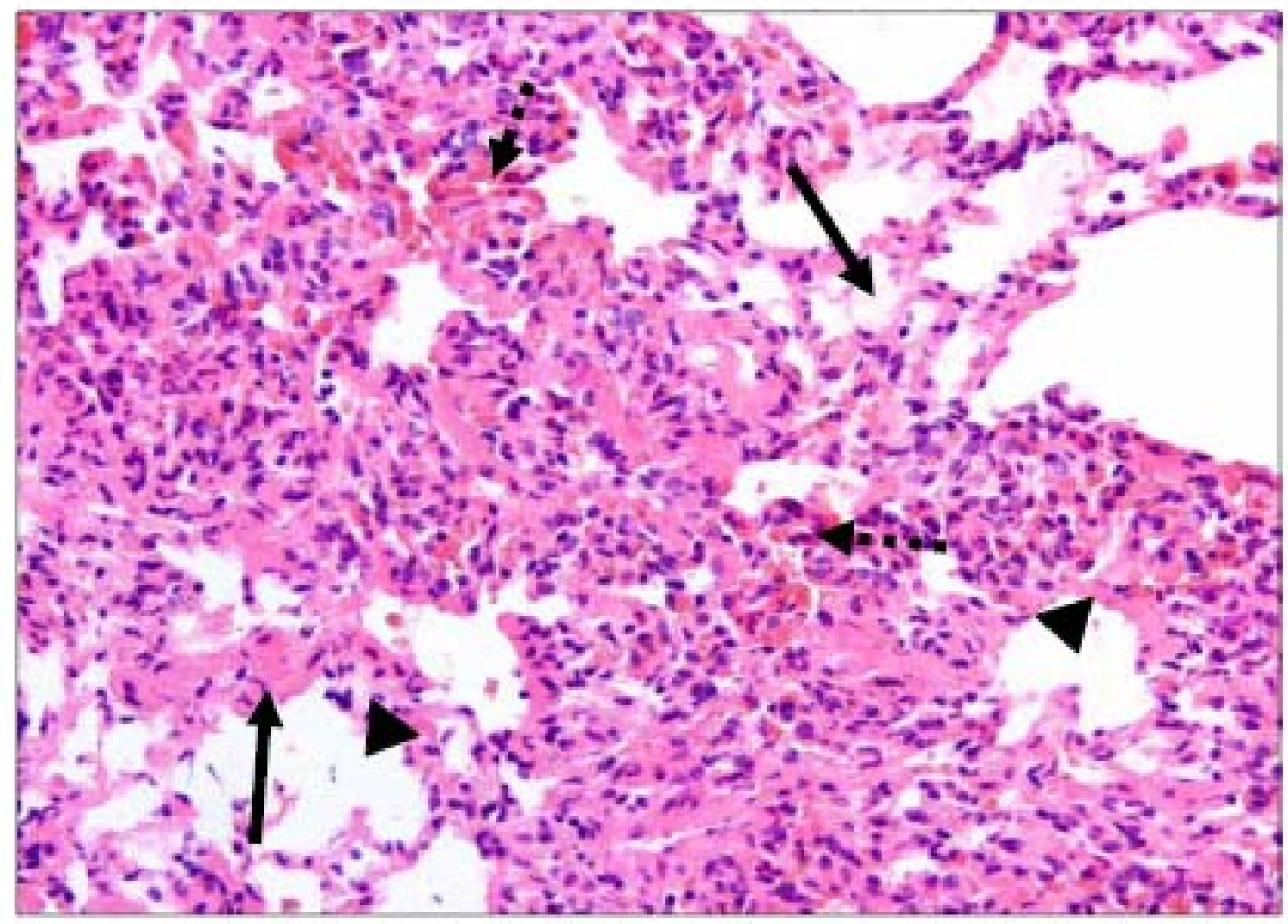


Figure 3

\section{Interstitial cells}

fig $3 a$

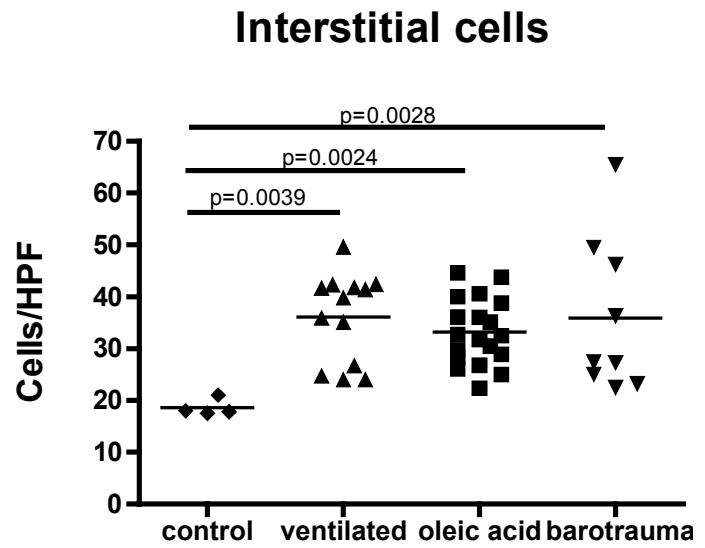

fig $3 b$

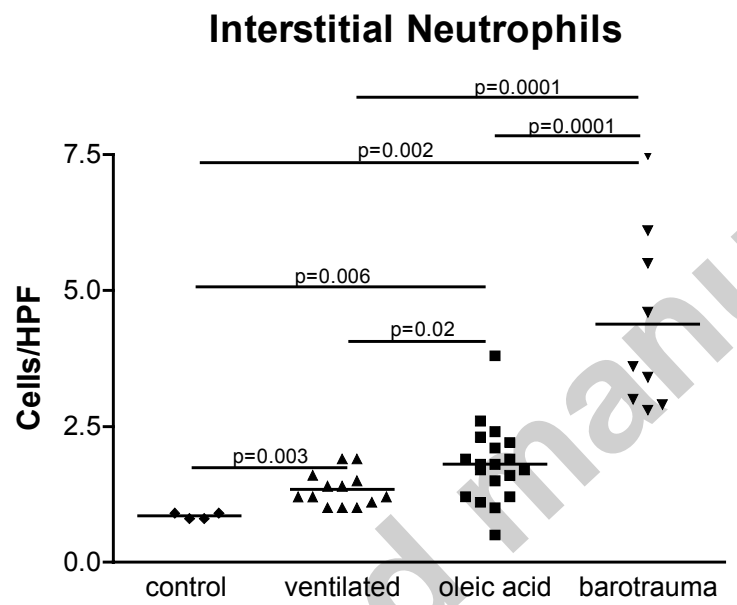

\section{Destruction of alveolar attachments}

fig $3 c$

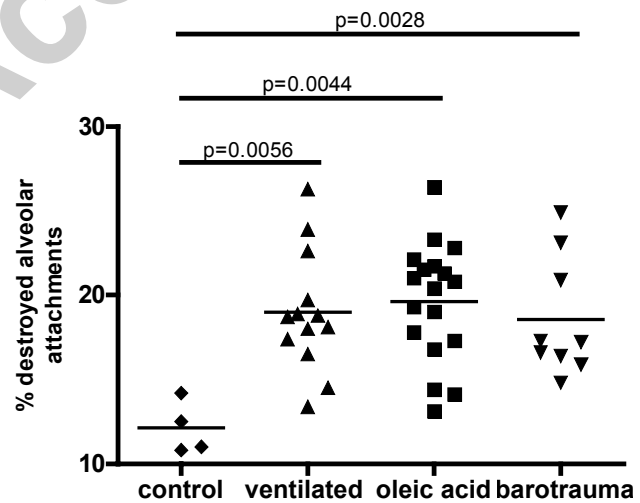


Figure 4

Fig. 4a

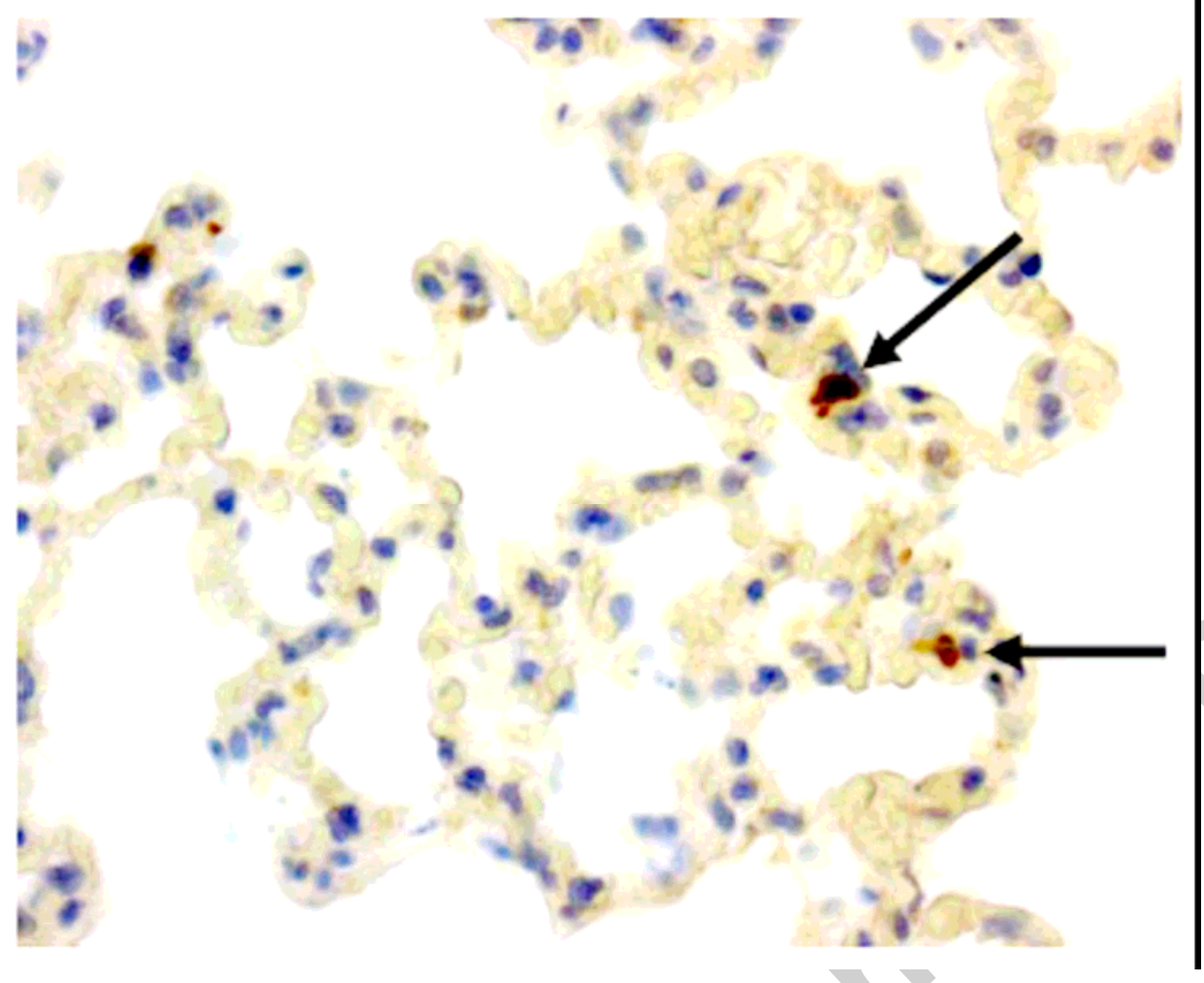

Fig. 4b

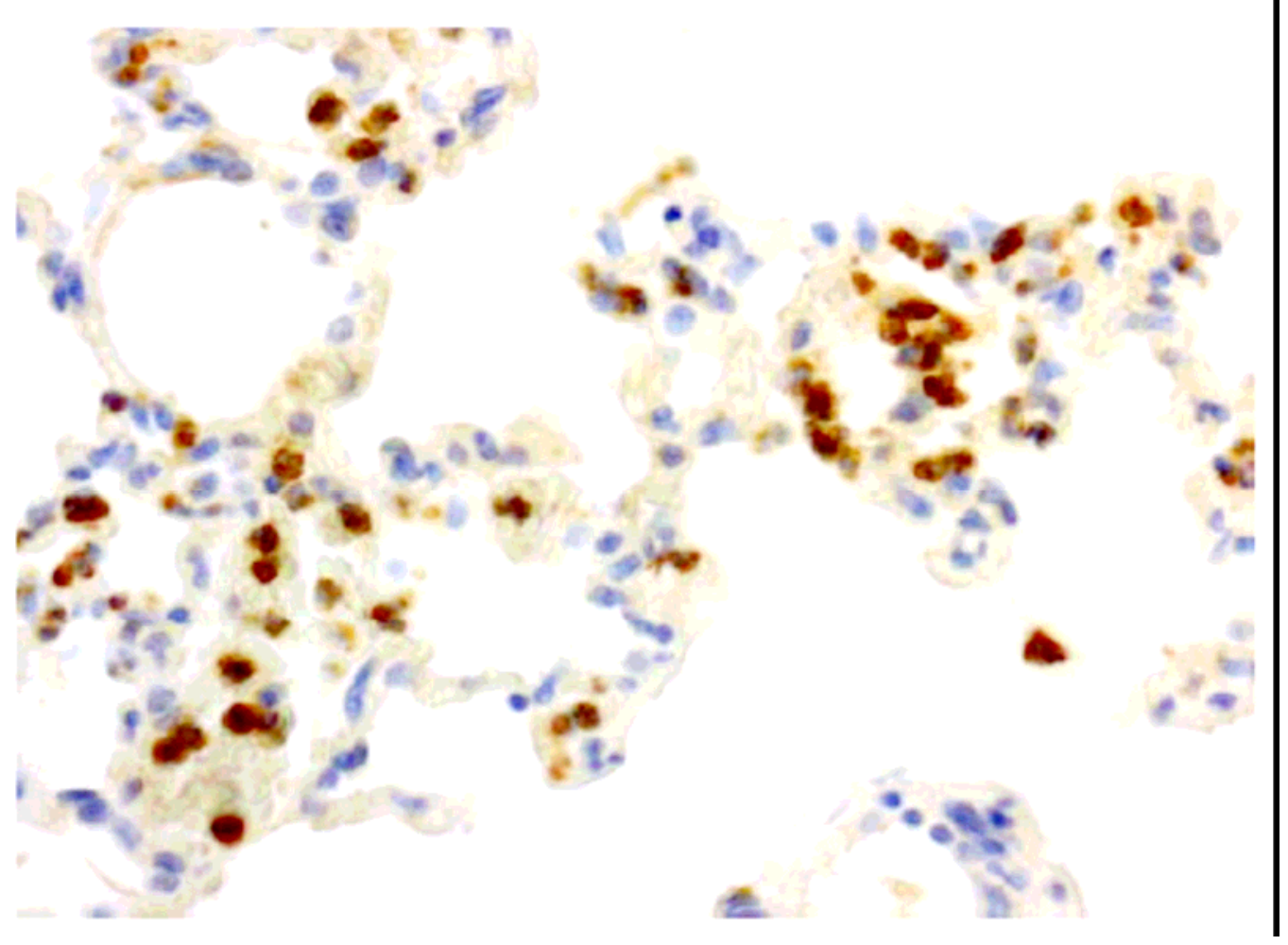


Figure 5

$\mathbf{G R} \alpha$

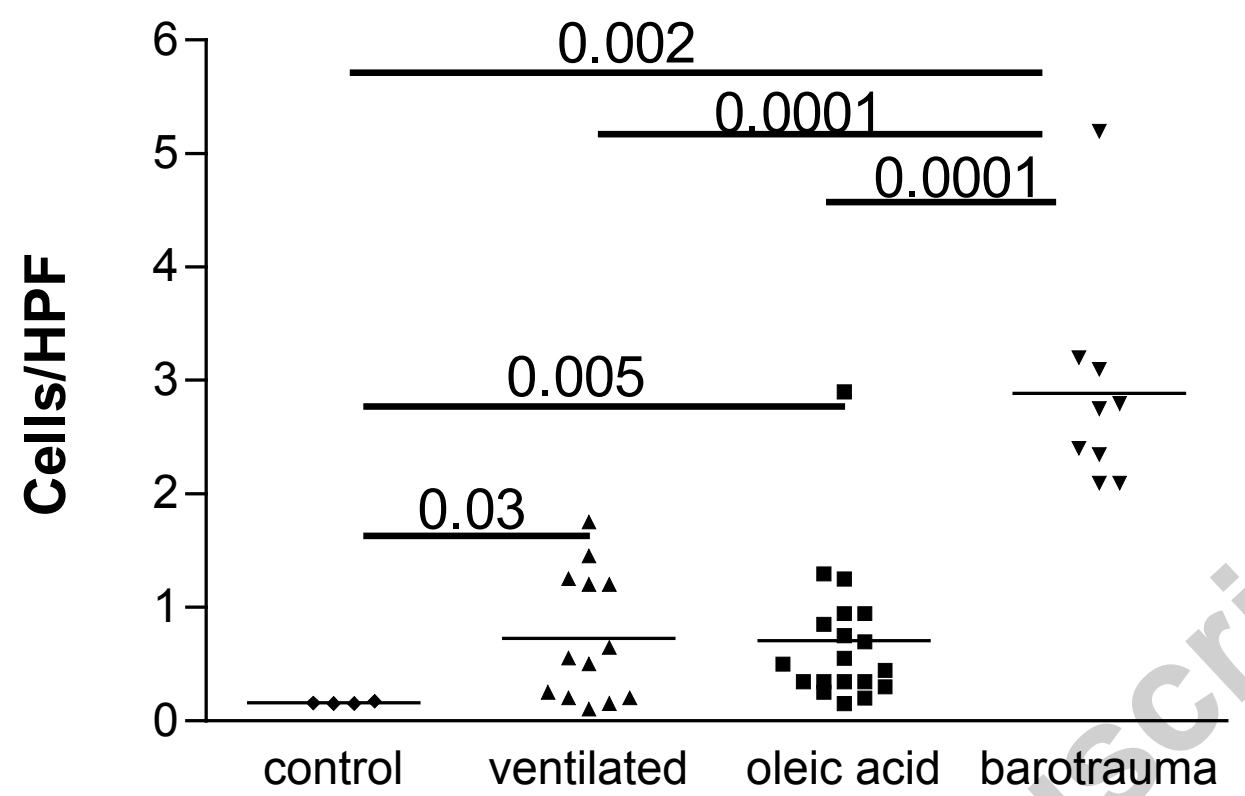

fig 5 
Figure 6

fig $6 a$

Neutrophils vs GR $\alpha$

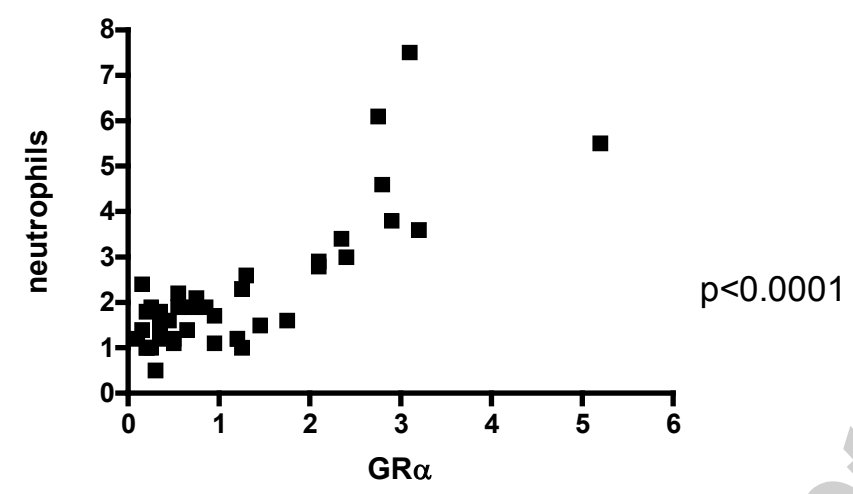

fig $6 b$

Weight vs neutrophils

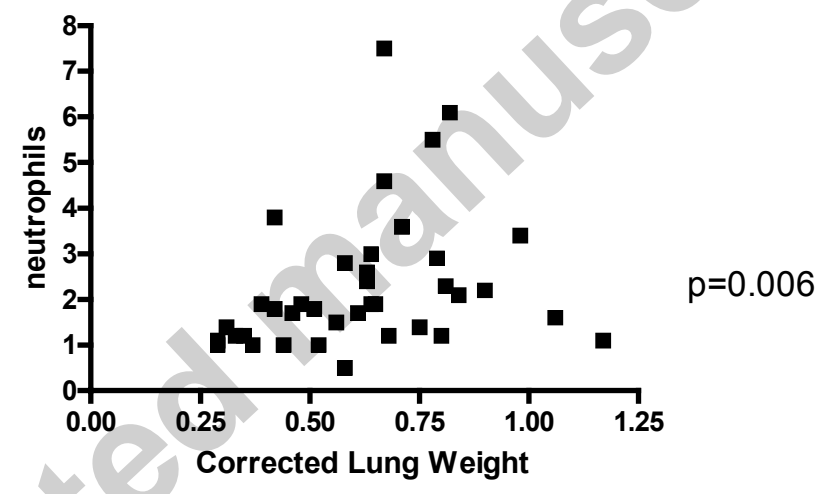

fig $6 c$

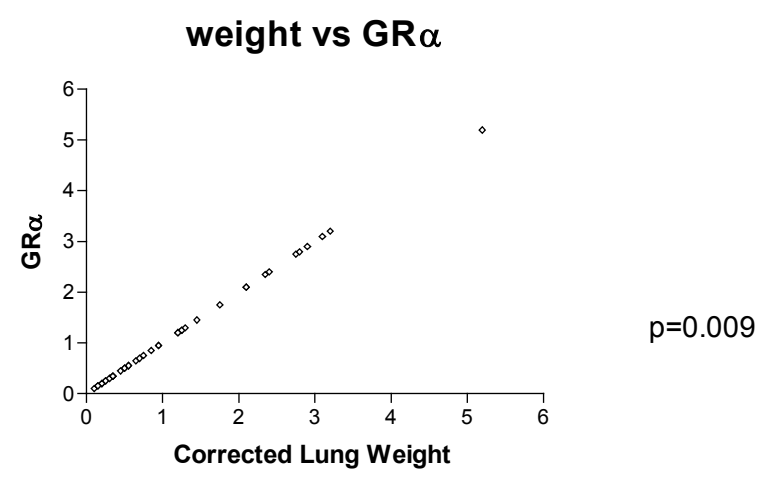

